\title{
Fungi in the Canopy: How Soil Fungi and Extracellular Enzymes Differ Between Canopy and Ground Soils
}

\author{
Caitlin I. Looby, ${ }^{1 *}$ Emily C. Hollenbeck, ${ }^{2}$ and Kathleen K. Treseder ${ }^{3}$
}

${ }^{1}$ Department of Ecology, Evolution and Behavior, University of Minnesota, Twin Cities, Minneapolis, Minnesota 55455, USA; ${ }^{2}$ Department of Ecology and Evolutionary Biology, Brown University, Providence, Rhode Island 02912, USA; ${ }^{3}$ Department of Ecology and Evolutionary Biology, University of California, Irvine, California 92697, USA

\begin{abstract}
Tropical montane cloud forests contain a large abundance and diversity of canopy epiphytes, which depend on canopy soil to retain water and nutrients. We lack an in depth understanding of how these soils contribute to ecosystem processes and soil diversity and how sensitive they may be to projected climate change. We compared canopy and ground soils in Monteverde, Costa Rica, to determine how these two soil types differ in their extracellular enzyme activity (EEA) and fungal communities. Samples were also collected along two elevation gradients to reveal if canopy soils differed in how EEA and fungal communities responded to elevation compared to ground soils. We found that canopy soils had higher EEA than ground soils. Fungal communities were less diverse and differed significantly between the two soil types. These differences were associated with
\end{abstract}

Received 24 January 2019; accepted 21 August 2019; published online 16 September 2019

Electronic supplementary material: The online version of this article (https://doi.org/10.1007/s10021-019-00439-w) contains supplementary material, which is available to authorized users.

Author's Contributions CIL conceived the study, conducted laboratory work, analyzed the data, and wrote the manuscript. ECH conducted fieldwork and wrote the manuscript. KKT conceived the study and wrote the manuscript. All authors contributed significantly to the current version.

*Corresponding author; e-mail: caitlin.looby@gmail.com higher relative abundances of yeasts and endophytes in canopy soils. The relative abundances of free-living filamentous fungi and yeasts shifted more dramatically with elevation in canopy soils compared to ground soils. Our study suggests that canopy soils may be a reservoir for endophytes. Epiphytes may invest in symbionts that promote stress tolerance over mycorrhizal fungi whose high resource demands are costly and less beneficial. Overall, soils harbor distinct fungal communities that may be altered under projected climate change.

Key words: canopy soil; extracellular enzymes; elevation gradients; endophytes; epiphytes; mycorrhizal fungi; tropical montane cloud forests (TMCFs).

\section{INTRODUCTION}

Tropical forests have a disproportionate influence over global biodiversity and C cycling (Townsend and others 2011). However, most of our understanding is limited to soils on the ground. This limitation is especially relevant for tropical montane cloud forests (TMCFs), which are structurally complex ecosystems owing to their characteristic cloud cover. Part of this structural complexity is the high abundance and diversity of canopy epiphytes (Gentry and Dodson 1987). Epiphytes consist of 
one-third of the foliar biomass in some forests (Nadkarni 1984). These epiphytes are often rooted in an arboreal organic mat containing canopy soil, which holds water and nutrients, allowing epiphytes to thrive in the harsh conditions within the canopy (Bohlman and others 1995; Nadkarni and others 2004). Indeed, canopy communities experience high winds, drier conditions, and higher UV radiation compared to the understory (Cardelús and Chazdon 2005).

Determining how canopy soils differ from ground soils will provide a better understanding of fungal biodiversity within canopy soils and how soil fungi might support epiphyte biomass. This issue is important, as canopy communities in TMCFs are now experiencing less cloud cover and longer dry periods due to climate change (Still and others 1999; Lawton and others 2001; Karmalkar and others 2011). Because they are disconnected from water sources on the ground, canopy communities are vulnerable to climate change, and may serve as biotic indicators of change (Nadkarni 2010; Gotsch and others 2016).

Canopy soils are derived from of dead organic matter from epiphytes and other plant material intercepted by branches in the canopy (Nadkarni and others 2004). The soils have a high water storage capacity (Bohlman and others 1995) and can consist of up to 45 percent of the nutrient capital in host-tree foliage (Nadkarni 1984). In addition, they may serve as reservoirs for plantfungal symbionts, like mycorrhizal fungi and endophytes. Endophytes reside in the aboveground tissues of plants for part of their life cycle and can also reside in soil. Mycorrhizal fungi can support epiphytes by promoting nutrient uptake and endophytic fungi can ameliorate drought stress.

Because of inaccessibility, few studies have investigated fungal community composition and diversity, and extracellular enzyme activity (EEA) in canopy soils. High organic matter in canopy soil correlates with higher fungal growth compared to ground soils (Rousk and Nadkarni 2009). In a lowland tropical forest, Pittl and others (2010) used quantitative PCR and denaturing gradient gel electrophoresis to explore differences in microbial communities. Dangerfield and others (2017) provided the first characterization of bacterial communities in canopy soils using high-throughput sequencing in a temperate rain forest. In addition, Orlovich and others (2013) characterized ectomycorrhizal fungi in canopy soils. But, we do not know what types of fungi are present in canopy soils and what functional roles they potentially fulfill. Any differences in the fungal community may have functional consequences in terms of EEA, as soil fungi are the primary produces of extracellular enzymes responsible for decomposition. Our study provides the first characterization of entire fungal communities in canopy soils using high-throughput sequencing.

Microclimate conditions in the canopy might affect the types of fungal functional groups present in canopy soils. Fungi are sensitive to changes in temperature and precipitation (Allison and Treseder 2008; Hawkes and others 2011; McGuire and others 2011), both of which can vary across elevation gradients. Indeed, elevation gradients are natural laboratories that allow us to investigate mechanisms that shape microbial diversity and community composition (Sundqvist and others 2013) and serve as proxies for climate change (Malhi and others 2010). For instance, if some fungal groups are more abundant at lower elevations that are warmer and drier, they may proliferate under future climate conditions in these forests. In a previous study, we demonstrated that soil properties and fungi shift with elevation in ground soils in a Costa Rican TMCF (Looby and others 2016). In the current study, we asked these questions: (1) Do canopy soils differ from ground soils in their properties, EEA, and fungal communities? (2) Do the two soil types differ in how they respond to elevation?

For the first question, we hypothesized that canopy soils would harbor lower levels of diversity, due to harsher conditions. This would be associated with shifts in fungal functional groups between canopy and ground soils, and EEA of C-degrading enzymes would be higher in canopy soils because of increased C. For the second question, we hypothesized that fungal community composition of canopy soils would be more sensitive to changes in elevation compared to ground soils due to greater microclimate variation and fluctuations in moisture content in the canopy. To test these hypotheses, we measured soil properties, EEA of Cdegrading enzymes, and fungal diversity and community composition in canopy and ground soils along elevation transects on the Atlantic and Pacific slopes of the Cordillera de Tilarán in Monteverde, Costa Rica.

\section{Materials AND Methods}

Field Sites and Collection

Two elevational transects were established in preserved forest in Monteverde, Costa Rica, in the Monteverde Cloud Forest Reserve $\left(10^{\circ} 18^{\prime} \mathrm{N}\right.$, 
$84^{\circ} 47^{\prime} \mathrm{W}$ ) and nearby private land. Eight sites in total spanned these transects from 850 to 1400 meters above sea level (m.a.s.l.) along the Atlantic slope and from 1150 to 1810 m.a.s.l. along the Pacific slopes (Table S1). The slopes vary in their climate and were analyzed separately throughout the study. Briefly, the Atlantic slope is on the windward side of the mountain range, and receives more rainfall, more water inputs from clouds (horizontal precipitation), and more wind than the Pacific slope (Häger and Dohrenbusch 2010). The Pacific slope-on the leeward side-has a steeper temperature and soil moisture gradient across elevation. The Pacific slope also experiences greater precipitation seasonality than the Atlantic, with greater distinction between seasons increasing at lower elevations.

Canopy and ground soil were collected from February 12 to March 9, 2014, during the dry season. The same trees were sampled at both time points. Three trees were sampled at each site, with a few exceptions. For instance, due to equipment failure, only two trees were ascended at 1200 m.a.s.l. (Atlantic). Only two climbable trees were present at 1760 m.a.s.l. (Pacific). Near the divide at 1810 m.a.s.l., high winds and frequent branch and tree falls make conditions dangerous for climbing, so soil was sampled from two partially fallen trunks resting approximately $1 \mathrm{~m}$ above the ground, with two samples per trunk taken $1 \mathrm{~m}$ apart. Since the "canopy" is stunted and disturbed in the elfin forest, the low trunks yield a realistic approximation of the canopy soil. Although 1760 and 1810 m.a.s.l. are similar elevations, trees at 1760 m.a.s.l. experience much less wind and mist due to their leeward position; thus, samples were analyzed separately.

Trees were climbed using standard Single Rope Technique. At each tree, a total of five soil samples were collected, two from the canopy and three from the ground. Canopy samples were collected from main branches. On the ground, three collections were made at a distance of $5 \mathrm{~m}$ from the main trunk and at least $5 \mathrm{~m}$ from each other. Ground soil samples were taken using a trowel (approximately $5 \mathrm{~cm}$ deep) to obtain the top organic layer of soil. Undecomposed organic matter was removed in both canopy and ground soils. Canopy soil was collected using a knife and small shovel described in Nadkarni and others (2004), obtaining approximately $5 \mathrm{~g}$ per sample. Soil samples were stored at $-20^{\circ} \mathrm{C}$ within $8 \mathrm{~h}$ post-collection.

\section{Soil Properties}

Soil temperature was measured on each branch and adjacent to soil samples collected on the ground for each tree and site. Soil temperature was also recorded from September 2014 to March 2015 using LogTag sensors (Figure S1). Subsamples were weighed, dried at $65^{\circ} \mathrm{C}$ for $48 \mathrm{~h}$, and then reweighed to determine gravimetric moisture content. Soil $\mathrm{pH}$ was determined using a $1: 2$ ratio $(\mathrm{w} / \mathrm{v})$ of soil to DI $\mathrm{H}_{2} \mathrm{O}$. Soil $\mathrm{C}$ and $\mathrm{N}$ concentrations were measured by combustion on an elemental analyzer (Flash EA 1112, Thermo Scientific, Waltham, MA) and used to determine percent $\mathrm{C}$ and $\mathrm{N}$, and soil $\mathrm{C} /$ $\mathrm{N}$ ratios.

\section{Fungal Community Composition}

Soil DNA was extracted from each sample with the PowerSoil DNA Isolation kit (MoBio, Carlsbad, CA, USA) following the manufacturer guidelines. DNA quality and concentrations were quantified using a NanoDrop and standardized to $10 \mathrm{ng} / \mu \mathrm{l}$ prior to PCR amplification. There were no significant differences in the DNA quantities measured in canopy versus ground soils. We used modified primers targeting the $5.8 \mathrm{~S}$ encoding gene to amplify the ITS2 region of fungal ribosomal encoding genes. Description of these primers and PCR parameters is explained in detail in Looby and others (2016). PCRs from each sample were run in triplicate, pooled, and purified with Agencourt AMPure XP magnetic beads (Beckman Coulter, Brea, CA). PCR were run with positive and negative (sterile molecular grade water) controls to ensure no background OTUs were incorporated into the final sample pool. We quantified purified samples using the Qubit dsDNA High Sensitivity Assay Kit (Life Technologies, Grand Island, NY). Purified samples were pooled separately in equimolar concentrations. The pooled samples were sequenced on one lane of an Illumina MiSeq sequencer as $2 \times 300 \mathrm{bp}$ paired end reads and spiked with 11 percent PhiX. Sequencing was performed at the Genomics Core in the Institute for the Integrative Genome Biology at the University of California, Riverside. Sequences were deposited in the NCBI database under the SRA accession number SRP148478.

We processed sequences using the Quantitative Insights Into Microbial Ecology (QIIME) pipeline (Caporaso and others 2010). Sequences were assembled and filtered for quality control. We re- 
tained sequences characterized by a minimum Phred score sequence cutoff threshold of 33 and higher. Sequences were discarded if they had less than $85 \%$ consecutive high-quality reads and more than two consecutive low-quality base reads. Chimeras were detected and removed using USEARCH 6.1 (v. 6.1.544), and global singletons were removed. After quality control, our high-quality sequences were clustered into operational taxonomic units (OTUs) at a 97\% similarity cutoff (Garnica and others 2016). One representative sequence from each OTU was chosen, and the closest taxonomic identity was determined via BLAST comparison in the GenBank database. A taxonomic assignment was made for each OTU using nomenclature classification in the UNITE database (v.7, release date 11-20-2016). To avoid bias due to differing library sizes, samples were normalized to 2416 sequences per sample.

We assigned functional groups to OTUs using the FUNGuild algorithm (Nguyen and others 2016). Functional groups are assigned at the genus and species level and with confidence levels of "highly probable," "probable," and "possible." Approximately $56 \%$ of OTUs were matched to a functional guild within the FUNGuild database. Only assignments with confidence levels of "highly probable" or "probable" were included in analyses $(87.9 \%$ of matched guilds). Fungal functional groups were categorized as follows: free-living filamentous fungi (saprotrophs and wood saprotrophs), endophytes (dark septate endophytes and endophytes), lichenforming fungi, mycorrhizal fungi (arbuscular mycorrhizal fungi and ectomycorrhizal fungi), pathogens (animal pathogens, mycoparasites, and plant pathogens), and yeasts.

\section{Extracellular Enzyme Assays}

Soil EEA for C-degrading enzymes was measured using a microplate fluorometric protocol (German and others 2011). These hydrolytic enzymes target labile to intermediate $\mathrm{C}$. They included $\alpha$-glucosidase (AG, starch degrading), $\beta$-glucosidase (BG, cellulose degrading), cellobiohydrolase $(\mathrm{CBH}$, cellulose degrading), and $\beta$-xylosidase (BX, hemicellulose degrading). Specific methods are summarized in Looby and others (2016). Soils were incubated at temperatures measured at the time of collection (Table S3). Substrates used included 4-MUB- $\beta-D-$ cellobioside (BG), 4-MUB- $\alpha$-D-glucopyranoside $(\mathrm{AG})$, 4-MUB- $\beta$-D-cellobioside (CBH), and 4MUB- $\beta$-D-Xylopyranoside (BX), and the florescent standard 4-methylumbelliferone (MUB, Fisher Scientific).

\section{Statistics}

To determine differences in soil properties and EEA between canopy and ground soils, and how the two soil types varied with elevation, and between slopes, we performed a mixed model using the nlme package in R (Pinheiro and others 2016). We included elevation as a continuous covariate, soil type and slope as fixed effects, and all samples were grouped by "Tree" to incorporate our paired sampling design. Differences in soil type are denoted by "Type," and differences in elevational responses between soil types are denoted by "Elevation*Type." We performed a separate mixed model for each soil and fungal parameter with tree as a random effect to determine how canopy and ground soils each respond to elevation (denoted by "Elevation"). Differences are considered significant when $P<0.050$. We also report the Elevation*Type*Slope interaction to show how elevational responses of the two soil types vary between the slopes. In all but one case (that is, soil moisture content), elevational responses between the soil types responded similarly across both slopes [that is, Elevation*Type*Slope interaction was not significant (Table 1)]. For this reason, we present the general pattern for both slopes, and for simplicity we plot both slopes together to show the general change in soil properties with elevation for each soil type. However, data from the two slopes are displayed as separate symbols across one elevation axis because although they show statistically similar patterns, they may not be the same biologically. Moreover, shifts across elevation are not always linear, but changes across elevation may still vary between canopy and ground soils. When shifts were linear across elevation ("Elevation" $P<0.050)$ this is denoted within the figures. To describe any covariance in the soil properties along the elevation gradients, we calculated Pearson correlation coefficients (Table S2). All statistical analyses were carried out using $\mathrm{R}$ ( $\mathrm{v}$. 3.3.2, R Development Core Team 2016).

Alpha diversity was computed for each sample using Shannon diversity index and observed number of OTUs. To assess differences in functional groups, we calculated relative abundances as proportion of OTUs in each sample. Proportions were determined for each sample by calculating the number of OTUs from each functional group in that sample, divided by the total number of OTUs found within that sample. We used a mixed model to determine differences in alpha diversity and relative abundance of functional groups between canopy and ground soils. Variables included elevation 
Table 1. Statistical Results for Differences in Soil Properties Between Ground and Canopy Soil Types (Type), Responses to Elevation (Elevation), and Differences in Elevational Responses Between Canopy and Ground Soils (Elevation*Type)

\begin{tabular}{|c|c|c|c|c|}
\hline Parameter & Slope & $\chi^{2}$ & $R^{2}$ & $P$ \\
\hline \multirow[t]{5}{*}{ Moisture } & Type & 28.9 & - & $<0.001$ \\
\hline & Elevation, canopy & - & 0.929 & 0.001 \\
\hline & Elevation, ground & - & 0.740 & 0.012 \\
\hline & Elevation*Type & 14.7 & - & $<0.001$ \\
\hline & Elevation*Type*Slope & 4.51 & - & 0.034 \\
\hline \multirow[t]{5}{*}{ Temperature } & Type & 36.6 & - & $<0.001$ \\
\hline & Elevation, canopy & - & 0.841 & $<0.001$ \\
\hline & Elevation, ground & - & 0.949 & $<0.001$ \\
\hline & Elevation*Type & 33.3 & - & $<0.001$ \\
\hline & Elevation*Type*Slope & 0.009 & - & 0.924 \\
\hline \multirow[t]{5}{*}{$\mathrm{pH}$} & Type & 94.6 & - & $<0.001$ \\
\hline & Elevation, canopy & - & 0.723 & 0.011 \\
\hline & Elevation, ground & - & 0.720 & 0.001 \\
\hline & Elevation*Type & 17.5 & - & $<0.001$ \\
\hline & Elevation*Type*Slope & 0.258 & - & 0.612 \\
\hline \multirow[t]{5}{*}{ Percent C } & Type & 386 & - & $<0.001$ \\
\hline & Elevation, canopy & - & 0.191 & 0.126 \\
\hline & Elevation, ground & - & 0.523 & 0.002 \\
\hline & Elevation*Type & 8.54 & - & 0.003 \\
\hline & Elevation*Type*Slope & 2.38 & - & 0.123 \\
\hline \multirow[t]{5}{*}{ Percent N } & Type & 40.5 & - & $<0.001$ \\
\hline & Elevation, canopy & - & 0.558 & 0.556 \\
\hline & Elevation, ground & - & 0.511 & 0.005 \\
\hline & Elevation*Type & 5.26 & - & 0.022 \\
\hline & Elevation*Type*Slope & 0.030 & - & 0.863 \\
\hline \multirow[t]{5}{*}{ Soil C/N } & Type & 97.4 & - & $<0.001$ \\
\hline & Elevation, canopy & - & 0.070 & 0.230 \\
\hline & Elevation, ground & - & 0.112 & 0.576 \\
\hline & Elevation*Type & 0.763 & - & 0.002 \\
\hline & Elevation*Type*Slope & 0.621 & - & 0.431 \\
\hline
\end{tabular}

Elevation*Type*Slope interactions show how soil type varies with elevation across the Atlantic and Pacific Slopes.

Significant $P$ values in bold.

as a continuous covariate, soil type and slope as fixed effects, and tree as a random effect. In addition, we used a PERMANOVA using Bray-Curtis dissimilarity to analyze fungal community composition as a function of soil type and properties measured (that is, elevation, temperature, moisture, $\mathrm{pH}, \mathrm{C} / \mathrm{N}$, and $\mathrm{C}$ ) with the adonis function in the Vegan package of $\mathrm{R}$ (Oksanen and others 2017). The PERMANOVA was run with each term added last in the model to evaluate variance explained when all other factors were accounted for (Kivlin and others 2014). Soil properties were considered significant if $P<0.050$ when values were added last. Non-metric multidimensional scaling (NMS) plots were constructed in $\mathrm{R}$ to visualize fungal community composition.

\section{Results}

\section{Soil Properties}

Soil properties differed between the canopy and ground soils (Figure 1; Table 1). Soil moisture content was lower in canopy soils compared to ground soils (Figure 1A; $\chi^{2}=28.9, P<0.001$ ). Soil temperature was higher in canopy soils (Figure $\left.1 \mathrm{~B} ; \chi^{2}=36.6, P<0.001\right)$. Canopy soils were also more acidic than ground soils (Figure 1C; $\left.\chi^{2}=94.6, \quad P<0.001\right)$. Percent $\mathrm{C}$ and $\mathrm{N}$ were higher in canopy soils (C: Figure 1D; $\chi^{2}=386$, $P<0.001 ; \mathrm{N}$ : Figure 1E; $\left.\chi^{2}=40.5, P<0.001\right)$. In addition, soil $\mathrm{C} / \mathrm{N}$ was higher in canopy soils (Figure 1F; $\chi^{2}=97.4, P<0.001$ ).

In several cases, canopy and ground soils differed in how soil properties varied with elevation, based on significant Elevation*Type interactions (Fig- 

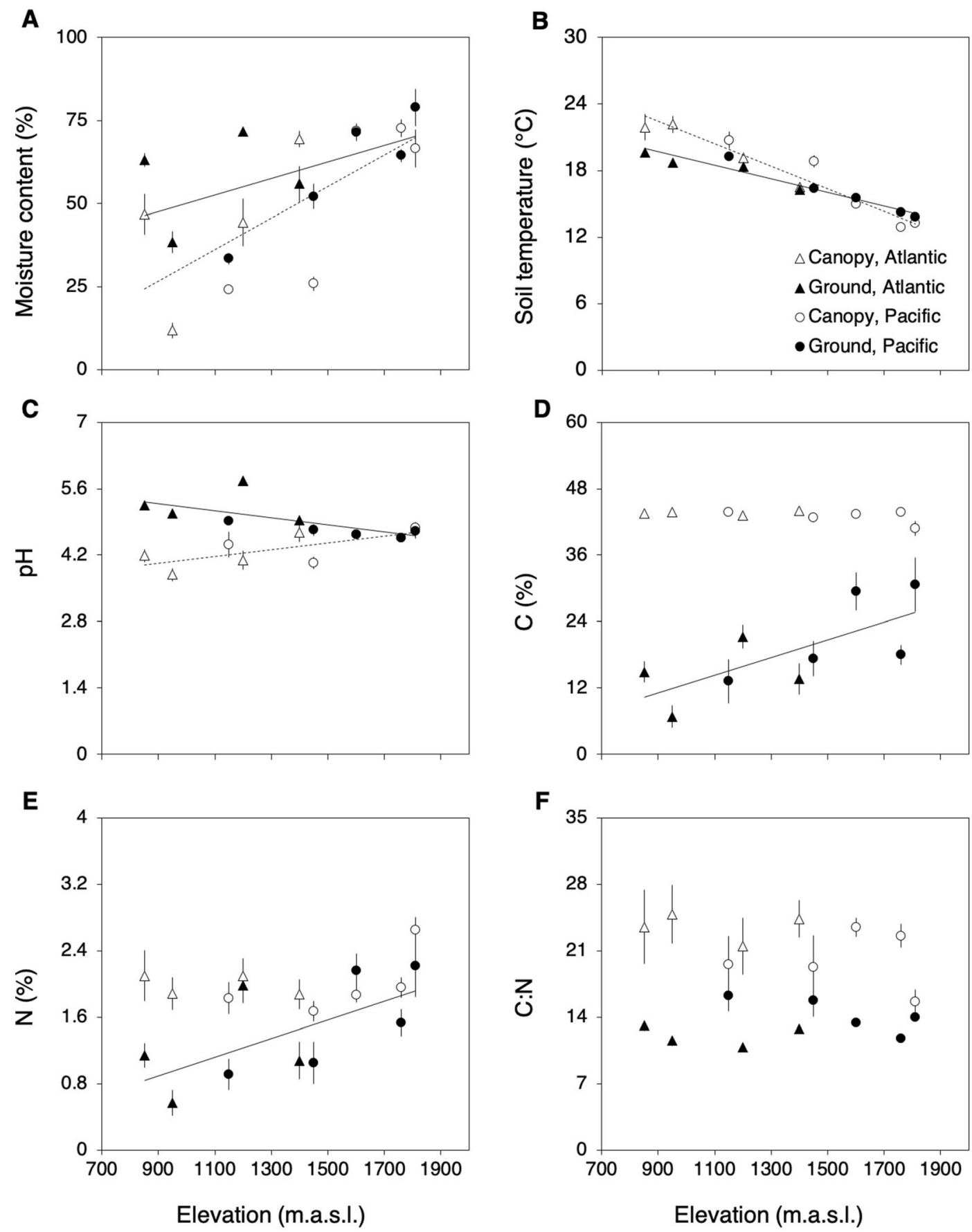

Figure 1. Soil properties by elevation in canopy (open symbols) and ground (closed symbols) soils. Canopy soils were A drier, $\mathbf{B}$ warmer, and $\mathbf{C}$ more acidic compared ground soils. There was also higher $\mathbf{D}$ percent $\mathbf{C}, \mathbf{E}$ percent $\mathrm{N}$, and $\mathbf{F}$ C/N ratios in canopy soils. Canopy and ground soils also differed in how moisture content, temperature, $\mathrm{pH}$, and percent $\mathrm{C}$ and $\mathrm{N}$ responded to elevation as indicated by a significant Elevation*Type interaction. There was no significant difference in how soil $\mathrm{C} / \mathrm{N}$ responded to elevation between the two soil types. Lines are significant best-fit regressions for canopy (dashed line) and ground (solid line) soils $(P<0.05)$. Triangles indicate samples from the Atlantic slope, and circles indicate samples from the Pacific slope. Symbols are mean \pm SE. Detailed statistical results are presented in Table 1.

ure 1; Table 1). Soil moisture content in canopy soils had a larger increase with increasing elevation than did ground soils (Figure 1A; $\chi^{2}=14.7$,
$P<0.001)$. Soil temperature in canopy soils declined more rapidly with increasing elevation than did ground soils (Figure 1B; $\chi^{2}=33.3, P<0.001$ ). 
Canopy soils became less acidic with increasing elevation, while ground soils became more acidic (Figure 1C; $\chi^{2}=17.5, P<0.001$ ). Percent $C$ increased significantly with elevation in ground soils, while percent $\mathrm{C}$ was consistent across elevations in canopy soils (Figure 1D; $\chi^{2}=8.54, \quad P=0.003$ ). Percent $\mathrm{N}$ had a greater increase with elevation in ground soils compared to canopy soils (Figure 1E; $\left.\chi^{2}=5.26, P=0.022\right)$. Canopy and ground soils did not significantly differ in how soil $\mathrm{C} / \mathrm{N}$ responded to elevation $(P>0.10)$.

\section{Fungal Diversity and Community Composition}

Fungal diversity was lower in canopy soils than ground soils (Table 1; Figures S2, S3), based on Shannon diversity (Figure S3A; $\chi^{2}=18.1$, $P<0.001)$ and the number of observed OTUs (Figure S3B; $\chi^{2}=13.4, P<0.001$ ). Fungal diversity did not differ between canopy and ground soils in their relationship with elevation $(P>0.050)$. Fungal community composition significantly differed between canopy and ground soils along both slopes (Figure 2; Table 2). In addition, fungal communities were significantly structured by soil type, elevation, slope, temperature, moisture content, $\mathrm{pH}$, percent $\mathrm{C}$, and soil $\mathrm{C} / \mathrm{N}$.

\section{Fungal Functional Groups}

Relative abundance of fungal functional groups also differed between canopy and ground soils (Figure 3; Table 3). Canopy soil had lower abundances of free-living filamentous fungi (Figure 3A; $\left.\chi^{2}=112, \quad P<0.001\right)$, higher abundances of endophytes (Figure 3B; $\chi^{2}=29.0, P<0.001$ ), and lower abundances of mycorrhizal fungi (Figure 3C; $\left.\chi^{2}=92.2, P<0.001\right)$ compared to ground soils. Canopy soils also had higher abundances of lichenforming fungi (Figure S4A; $\chi^{2}=34.4, P<0.001$ ) and yeasts (Figure 3D; $\chi^{2}=35.2, \quad P<0.001$ ). There was no significant difference between abundance of pathogens between the two soil types (Figure S4B; $P>0.10$ ).

Canopy soils differed in how the relative abundance of free-living filamentous fungi responded to elevation compared to ground soils based on Elevation*Type interactions (Figure 3A; Table 3), although without a clear linear trend $\left(\chi^{2}=8.15\right.$, $P=0.004)$. Canopy and ground soils had a marginally significant difference in how the relative abundance of endophytes responded to elevation (Figure 3B; $\chi^{2}=3.74, P=0.054$ ), with endophyte

Table 2. PERMANOVA Results for Fungal Community Composition as a Function of Soil Type (Canopy, Ground), Elevation, Slope (Atlantic, Pacific), and Soil Properties

\begin{tabular}{lll}
\hline Environmental parameter & $R^{2}$ & $P$ \\
\hline Soil type & 0.688 & $\mathbf{0 . 0 1 4}$ \\
Elevation & 0.718 & $\mathbf{0 . 0 1 5}$ \\
Slope & 0.742 & $\mathbf{0 . 0 1 5}$ \\
Moisture content & 0.564 & $\mathbf{0 . 0 1 2}$ \\
Temperature & 0.459 & $\mathbf{0 . 0 0 9}$ \\
pH & 0.640 & $\mathbf{0 . 0 1 3}$ \\
Percent C & 0.479 & $\mathbf{0 . 0 1 0}$ \\
Soil C/N & 0.451 & $\mathbf{0 . 0 1 0}$ \\
& & \\
Significant $P$ values in bold. & & \\
\hline
\end{tabular}

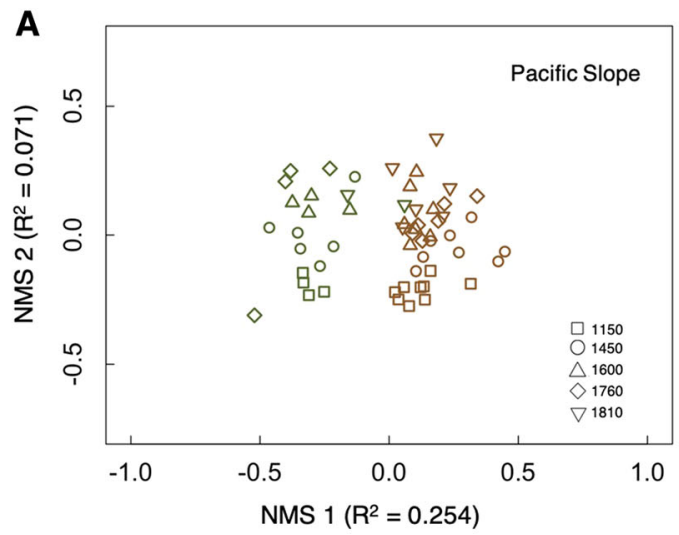

Figure 2. Non-metric multidimensional scaling (NMS) ordination showing differences in fungal community composition between canopy (green) and ground (brown) soils along the A Pacific and B Atlantic slopes. Canopy and ground soils differed significantly in fungal community composition $(P=0.014)$ across slopes. Fungal communities also structured based on elevation, slope, and soil properties (Table 2). Each symbol represents one sample. Elevations are represented by different symbols (Color figure online). 

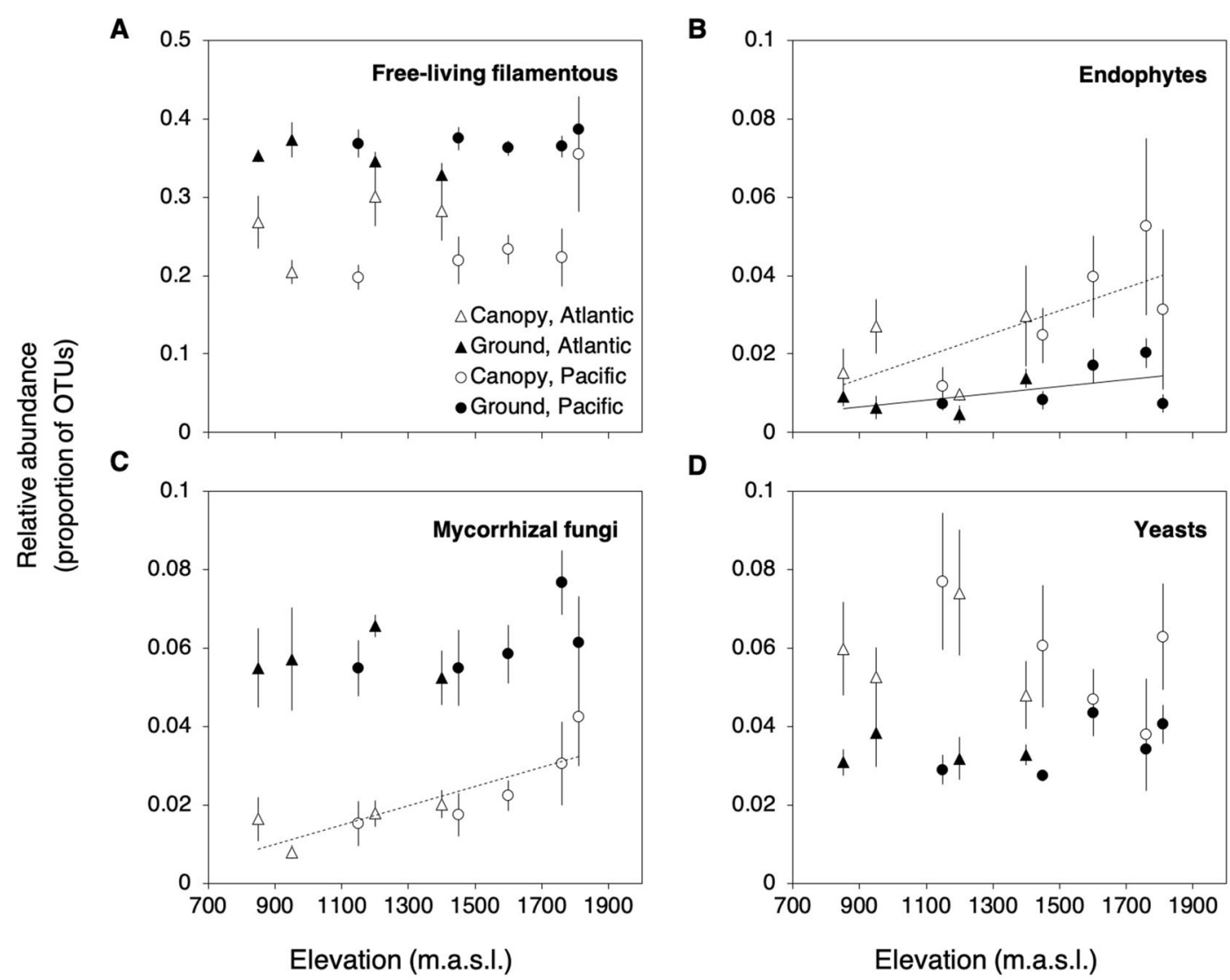

D

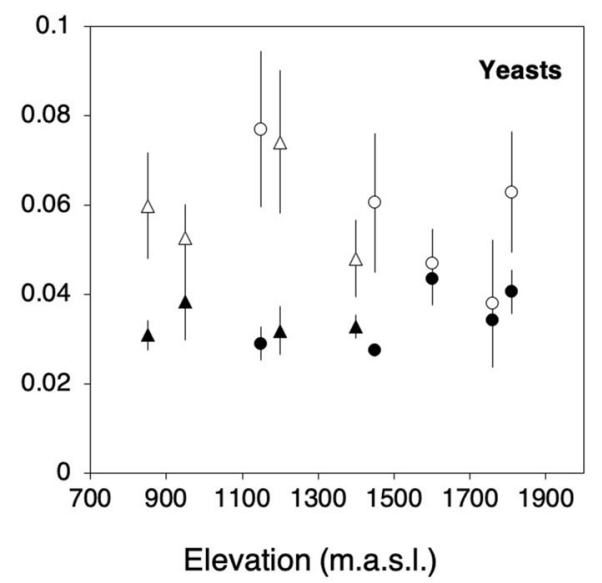

Figure 3. Relative abundance of fungal functional groups with elevation in canopy (open symbols) versus ground (closed symbols) soils. Canopy soils had a lower abundance of $\mathbf{A}$ free-living filamentous and $\mathbf{C}$ mycorrhizal fungi and higher abundance of $\mathbf{B}$ endophytes and D compared to ground soils. Canopy soils also had higher abundance of lichen-forming fungi (Figure S4). There was no significant difference between the relative abundance of pathogens between the two soil types (Figure S4). The relative abundance of free-living filamentous fungi and yeasts also differed in how they varied with elevation between the two soil types as indicated by a significant Elevation*Type interaction. There was a marginally significant difference in how the relative abundance of endophytes varied with elevation between canopy and ground soil. Triangles indicate samples from the Atlantic slope, and circles indicate samples from the Pacific slope. Symbols are mean \pm SE. Lines are significant best-fit regressions for canopy (dashed line) and ground (solid line) soils. Detailed statistical results are presented in Table 3.

abundance increasing more dramatically with elevation in canopy soils. Lichen-forming fungi varied more widely with elevation in canopy soils than ground soils, but with inconsistent trends across elevation (Figure S4A; $\chi^{2}=10.4, P=0.001$ ). In canopy soils, the relative abundance of yeasts tended to decline with elevation, but tended to increase in ground soils (Figure 3D; $\chi^{2}=5.51$, $P=0.019)$. Both relationships were subtle, though. There were no significant differences in how the relative abundances of mycorrhizal fungi and pathogens responded to elevation $(P>0.10)$.

\section{Extracellular Enzyme Activity}

Potential EEA of all enzymes was higher in canopy soils than ground soils (Figure 4; Table 4). Specifi- cally, canopy soils had significantly higher activities of AG $\left(\chi^{2}=31.6, \quad P<0.001\right), \quad$ BG $\quad\left(\chi^{2}=31.2\right.$, $P<0.001)$, $\mathrm{CBH}\left(\chi^{2}=7.30, P=0.007\right)$, and $\mathrm{BX}$ $\left(\chi^{2}=9.36, P=0.002\right)$ on both slopes. Canopy soils differed in how activities of $\mathrm{BG}, \mathrm{CBH}$, and $\mathrm{BX}$ responded to elevation compared to ground soils based on Elevation*Type interactions (Table 4), but with inconsistent trends across elevation.

\section{Discussion}

Much of the structural complexity in TMCF comes from the abundance and diversity of epiphytes that reside in the canopy (Gentry and Dodson 1987). These epiphytes often root in canopy soil, which is composed of highly organic material and retains water and nutrients, making it an important re- 
Table 3. Statistical Results in Fungal Communities Between Canopy and Ground Soil Types (Type), Responses to Elevation (Elevation), and Differences in Elevational Responses Between Canopy and Ground Soils (Elevation*Type)

\begin{tabular}{|c|c|c|c|c|c|}
\hline Category & Parameter & Slope & $\chi^{2}$ & $R^{2}$ & $P$ \\
\hline \multirow{10}{*}{ Fungal diversity } & \multirow{5}{*}{ Shannon diversity } & Type & 18.1 & - & $<0.001$ \\
\hline & & Elevation, canopy & - & 0.374 & 0.703 \\
\hline & & Elevation, ground & - & 0.293 & 0.033 \\
\hline & & Elevation*Type & 0.292 & - & 0.589 \\
\hline & & Elevation*Type*Slope & 3.26 & - & 0.071 \\
\hline & \multirow[t]{5}{*}{ Observed OTUs } & Type & 13.4 & - & $<0.001$ \\
\hline & & Elevation, canopy & - & 0.058 & 0.423 \\
\hline & & Elevation, ground & - & 0.235 & 0.130 \\
\hline & & Elevation*Type & 0.644 & - & 0.422 \\
\hline & & Elevation*Type*Slope & 3.06 & - & 0.080 \\
\hline \multirow[t]{30}{*}{ Functional groups } & \multirow[t]{5}{*}{ Free-living filamentous } & Type & 112 & - & $<0.001$ \\
\hline & & Elevation, canopy & - & 0.343 & 0.393 \\
\hline & & Elevation, ground & - & 0.007 & 0.510 \\
\hline & & Elevation*Type & 8.15 & - & 0.004 \\
\hline & & Elevation*Type*Slope & 0.038 & - & 0.845 \\
\hline & \multirow[t]{5}{*}{ Endophytes } & Type & 29.0 & - & $<0.001$ \\
\hline & & Elevation, canopy & - & 0.173 & 0.023 \\
\hline & & Elevation, ground & - & 0.416 & 0.041 \\
\hline & & Elevation*Type & 3.72 & - & 0.054 \\
\hline & & Elevation*Type*Slope & 1.64 & - & 0.200 \\
\hline & \multirow[t]{5}{*}{ Lichen-forming } & Type & 34.4 & - & $<0.001$ \\
\hline & & Elevation, canopy & - & 0.379 & 0.674 \\
\hline & & Elevation, ground & - & 0.305 & 0.464 \\
\hline & & Elevation*Type & 10.4 & - & 0.001 \\
\hline & & Elevation*Type*Slope & 0.011 & - & 0.915 \\
\hline & \multirow[t]{5}{*}{ Mycorrhizal } & Type & 92.2 & - & $<0.001$ \\
\hline & & Elevation, canopy & - & 0.220 & 0.002 \\
\hline & & Elevation, ground & - & 0.016 & 0.310 \\
\hline & & Elevation*Type & 0.508 & - & 0.476 \\
\hline & & Elevation*Type*Slope & 0.017 & - & 0.895 \\
\hline & \multirow[t]{5}{*}{ Pathogens } & Type & 2.37 & - & 0.122 \\
\hline & & Elevation, canopy & - & 0.058 & 0.811 \\
\hline & & Elevation, ground & - & 0.014 & 0.334 \\
\hline & & Elevation*Type & 1.19 & - & 0.276 \\
\hline & & Elevation*Type*Slope & 0.131 & - & 0.717 \\
\hline & \multirow[t]{5}{*}{ Yeasts } & Type & 35.2 & - & $<0.001$ \\
\hline & & Elevation, canopy & - & 0.146 & 0.344 \\
\hline & & Elevation, ground & - & 0.018 & 0.273 \\
\hline & & Elevation*Type & 5.51 & - & 0.019 \\
\hline & & Elevation*Type*Slope & 2.54 & - & 0.111 \\
\hline
\end{tabular}

Elevation*Type*Slope interactions show how soil type varies with elevation across the Atlantic and Pacific Slopes. Significant $P$ values in bold.

source for canopy dwellers (Nadkarni and others 2004). Although disconnected from the ground, these soils may promote net primary productivity by supporting epiphyte growth. Epiphyte structure, distribution, and conservation have been described (Coxson and Nadkarni 1995), but there are knowledge gaps in how soil fungi support epiphyte communities. Our study is one of the first to investigate how fungal communities differ between canopy and ground soils.

In Monteverde, TMCF are projected to experience decreased cloud immersion (Still and others 1999; Nair and others 2003) and longer periods without rain in the dry season (Pounds and others 1999, 2006; Karmalkar and others 2011). Canopy communities are extremely vulnerable to climate change (Nadkarni 2010), especially in cloud forests 


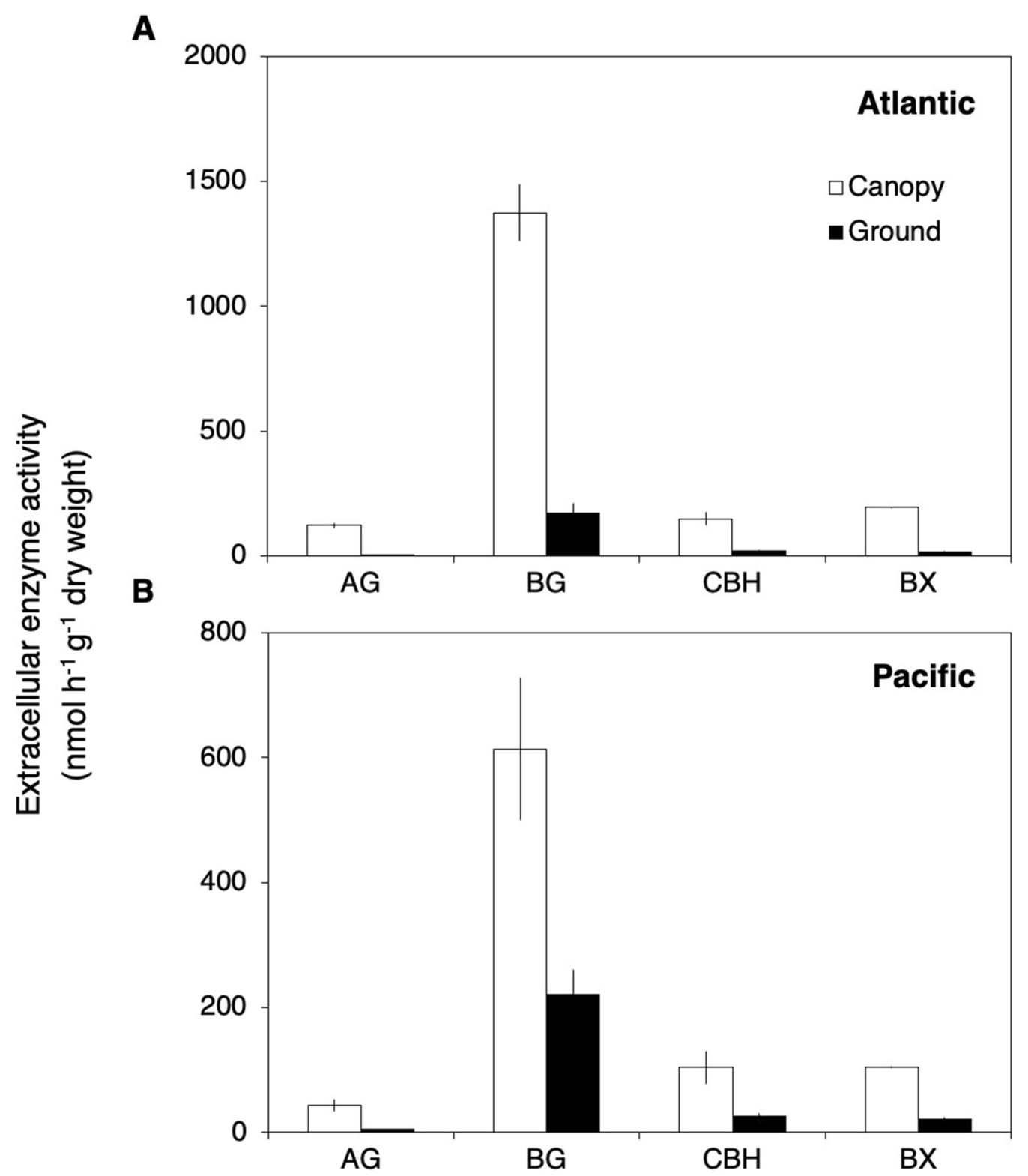

Figure 4. Potential extracellular enzyme activity (EEA) in canopy (open bars) and ground (closed bars) soils. Activities of $\alpha$ glucosidase (AG), $\beta$-glucosidase (BG), cellobiohydrolase $(\mathrm{CBH})$, and $\beta$-xylosidase $(\mathrm{BX})$ were all higher in canopy soils in both A Atlantic and B Pacific slopes. Canopy and ground soils also differed significantly in how activities of BG, CBH, and $\mathrm{BX}$ responded to elevation as indicated by a significant Elevation*Type interaction, but without consistent linear trends. There was a marginally significant difference in how AG activity varied with elevation between the two soil types. Symbols are mean \pm SE. Detailed statistical results are presented in Table 4.

where epiphytes are slow to recover from drought (Gotsch and others 2017). Therefore, we also performed this study along an elevation gradient to assess differences in how these canopy soils respond to climate gradients.

\section{Soil Properties}

We found overall support for our hypothesis that canopy soils would differ from ground soils in soil moisture, temperature, $\mathrm{pH}$, percent $\mathrm{C}$ and $\mathrm{N}$, and $\mathrm{C} / \mathrm{N}$ ratios. Our results agree with previous studies (for example, Aubrey and others 2013; Nadkarni and others 2002; Pittl and others 2010). We also found that moisture content increases more strongly with elevation in canopy soils compared to ground soils. Although canopy soils have a high water holding capacity (Bohlman and others 1995), they experience extremes in drying and rewetting (Coxson and Nadkarni 1995). This variability may 
Table 4. Statistical Results for Differences in Soil Types (Type), Responses to Elevation (Elevation), and Differences in Elevational Responses Between Canopy and Ground Soils (Elevation*Type)

\begin{tabular}{llllr}
\hline Extracellular enzyme activity & Slope & $\chi^{2}$ & $R^{2}$ & $P$ \\
\hline$\alpha$-Glucosidase (AG) & Type & 31.6 & - & $<\mathbf{0 . 0 0 1}$ \\
& Elevation, canopy & - & 0.486 & $\mathbf{0 . 0 2 6}$ \\
& Elevation, ground & - & 0.007 & 0.530 \\
& Elevation*Type & 3.73 & - & 0.053 \\
$\beta$-Glucosidase (BG) & Elevation*Type*Slope & 0.012 & - & 0.914 \\
& Type & 31.2 & - & $\mathbf{0 . 0 0 1}$ \\
& Elevation, canopy & - & 0.607 & $\mathbf{0 . 0 3 3}$ \\
& Elevation, ground & - & 0.230 & 0.519 \\
& Elevation*Type & 4.92 & - & $\mathbf{0 . 0 2 7}$ \\
Cellobiohydrolase $(\mathrm{CBH})$ & Elevation*Type*Slope & 1.73 & - & 0.189 \\
& Type & 34.8 & - & $\mathbf{0 . 0 0 1}$ \\
& Elevation, canopy & - & 0.544 & 0.057 \\
& Elevation, ground & - & 0.346 & 0.589 \\
$\beta$-Xylosidase (BX) & Elevation*Type & 7.30 & - & $\mathbf{0 . 0 0 7}$ \\
& Elevation*Type*Slope & 0.564 & - & 0.453 \\
& Type & 45.2 & - & $\mathbf{0 . 0 0 1}$ \\
& Elevation, canopy & - & 0.573 & $\mathbf{0 . 0 2 0}$ \\
& Elevation, ground & - & 0.192 & 0.897 \\
& Elevation*Type & 9.36 & - & $\mathbf{0 . 0 0 2}$ \\
& Elevation*Type*Slope & 0.981 & - & 0.322
\end{tabular}

Elevation*Type*Slope interactions show how soil type varies with elevation across Atlantic and Pacific Slopes. We tested differences in extracellular enzyme activities of C degrading enzymes. Differences were determined using a mixed model, with elevation as a continuous covariate, soil type and slope as fixed effects, and tree as a random effect.

become more extreme under future climate change, accentuating drought conditions for epiphytes. Decreased cloud immersion may reduce the amount of moisture received from cloud water and allow more light to hit these forests, thus increasing environmental stress for epiphytes.

In addition, we found that canopy soils had higher temperatures. Furthermore, soil temperature declined more with increasing elevation in canopy soils compared to ground soils. In Monteverde, there is greater microclimate variability (Clark and others 2000) and less cloud cover (Goldsmith and others 2012) in the dry season. Less cloud cover-and thus more light-may cause a greater temperature difference between the canopy and the ground. In a study comparing temperature differences between canopy soils and the organic horizon in a temperature rainforest, Aubrey and others (2013) found greater temperature fluctuations in canopy soils compared to ground soils.

Moreover, canopy soils in these forests are highly organic (Clark and others 2000). This characteristic is most likely why they are more acidic and have higher percent $\mathrm{C}, \mathrm{C} / \mathrm{N}$ ratios, and compared to ground soils. Previous studies also found that canopy soils in these forests were more acidic and had higher percent $\mathrm{C}$ and $\mathrm{N}$, albeit with no significant difference in soil $\mathrm{C} / \mathrm{N}$ between the two soil types (Nadkarni and others 2002; Pittl and others 2010).

\section{Fungal Diversity and Community Composition}

We found overall support for our hypothesis that diversity would be lower in canopy soils and that fungal community composition would differ between canopy and ground soils. Dangerfield and others (2017) found lower bacterial diversity in canopy soils than ground soils in a temperate rainforest. In a lowland forest in Costa Rica, Pittl and others (2010) used quantitative PCR and found no difference in fungal abundance between canopy and ground soils. The warmer temperatures, drought, strong winds, and high UV radiation typical of the canopy (Bohlman and others 1995) may increase fungal abundance, but may exclude certain taxa (Decaëns 2010), decreasing the fungal diversity in the canopy.

\section{Fungal Functional Groups}

Our results support the hypothesis that fungal functional groups would differ between soil types. We also acknowledge uncertainty in functional group assignments at our $97 \%$ similarity cutoff. We 
found a higher abundance of free-living filamentous fungi in ground soils. These fungi include wood saprotrophs that specialize in decomposing more recalcitrant forms of $\mathrm{C}$, like lignin (Treseder and Lennon 2015). There may be less fungi that specialize in breaking down recalcitrant $\mathrm{C}$ in canopy soils. Instead, there was a higher abundance of yeasts, which specialize in decomposing simple $\mathrm{C}$, like sugars, and are often found in more stressful environments.

Other studies show that the forest floor in Neotropical cloud forests tend to have a high abundance of mycorrhizal fungi compared to the canopy (Maffia and others 1993), although the canopy is suitable for this group of fungi (Rains and others 2003). Although percent $\mathrm{N}$ is higher in canopy soils, higher $\mathrm{C} / \mathrm{N}$ ratios suggest that there is low $\mathrm{N}$ availability in canopy soils and that the $\mathrm{N}$ present may not be bioavailable. Moreover, mycorrhizal fungi may not be easily dispersed between canopy and ground soils, and the specific microclimate conditions and extreme fluctuations may constrain colonization and establishment of mycorrhizal fungi (Hertel and others 2011). However, more process-oriented studies need to be conducted to track $\mathrm{N}$ dynamics within canopy soils to describe the mechanism driving this pattern.

In contrast, endophytes were more abundant in canopy soils. Hertel and others (2011) also found that canopy roots lacked mycorrhizal colonization, but had a large abundance of endophytic fungi. Almost all terrestrial plants are colonized by endophytes and benefit their hosts via improved stress tolerance. These fungi are horizontally transmitted and for part of their life cycle reside in soils. Endophytes confer stress resistance by reducing plant water loss and improve plant survival and growth in warmer, drier conditions (Giauque and Hawkes 2013; Giauque and others 2018). For instance, fungi produce osmolytes that help plants maintain turgor pressure (Yancey 2005; Hamilton and Bauerle 2012) and antioxidants that reduce reactive oxygen species in plants (Gorbushina and others 2014; Rodriguez and others 2008). The distribution of endophytic fungi is also based largely on changes in temperature and rainfall and less on plant host traits (Giauque and Hawkes 2016; Zimmerman and Vitousek 2012). Thus, endophytes may be particularly beneficial for epiphyte survival, which can experience water stress during warmer and drier periods (Hietz and others 2002), especially on smaller trees (Woods and others 2015). Increased colonization of endophytes and a lack of colonization of mycorrhizal fungi suggests that epiphytes invest more so in plant partners that promote stress tolerance over nutrient acquisition. The resource demands of mycorrhizal fungi may be costly and less beneficial to epiphytes and therefore result in greater investment in endophytes during stressful conditions.

\section{Extracellular Enzyme Activity}

We found support for our hypothesis that EEA of C-degrading enzymes would be higher in canopy soils. Other studies have found conflicting results in rates of decomposition between canopy and ground soils. One study found that decomposition of a common substrate was slower in the canopy (Cardelús 2009), while another found high activity of $\mathrm{N}$-degrading enzymes in bromeliad tanks (Inselsbacher and others 2007). Our results suggest that there may be a greater capacity of soil fungi to decompose $\mathrm{C}$ in canopy soils.

Soils with higher organic matter concentrations can lead to increased EEA (Sinsabaugh and others 2008). Higher percent $C$ is most likely contributing to the higher EEA found in canopy soils. Another study in Monteverde found that canopy soil had similar microbial activity and biomass compared to ground soil (Vance and Nadkarni 1990). Fungi are the main producers of hydrolytic enzymes (Schneider and others 2012), and they dominate decomposition of cellulose and hemicellulose (de Boer and others 2005). Differences in fungal community composition may have contributed to differences in EEA between soil types because fungi specialize in breaking down different forms of $\mathrm{C}$ (Setälä and McLean 2004; Hanson and others 2008; McGuire and others 2010). Because percent C was relatively constant across elevations in canopy soil, these changes in EEA were mostly likely due to changes in the fungal community and greater activity in warmer, drier conditions.

\section{ConClusions}

Our study is one of the first to use high-throughput sequencing to investigate how canopy and ground soils differ in fungal community composition. Because this approach is relatively comprehensive, it allowed us a deeper understanding of how soil fungi within canopy soils contribute to soil biodiversity and support epiphyte communities in TMCF. It is possible that stressful conditions in the canopy may drive differences in fungal community composition between canopy and ground soils. We also assessed how soil fungi vary with elevation in these two soil types. Our results suggest that for 
certain soil properties, differences between canopy and ground soils may be accentuated by climate change. For instance, more frequent and extreme fluctuations in temperature and moisture may increase recruitment of endophytes. Consequently, our study deepens our understanding of soil biodiversity in TMCF and how canopy and ground soils may differ in their elevational responses.

\section{ACKNOWLEDGEMENTS}

We thank S. Allison, J. Chaves, M. Goulden, and A. Romero-Olivares for intellectual feedback. We also thank L. Cat and M. Gorris for comments on previous drafts. T. Obando assisted in collecting soil samples. S. Do and F. Aguirre assisted in laboratory analyses. We thank the Leiton family and the Monteverde Cloud Forest Biological Reserve for access to field sites. Fieldwork associated with this study was performed with permission from the Costa Rica Ministry of Energy and the Environment. C. Looby was supported by the Newkirk Center at UCI, the Department of Education, the EPA, and a Doctoral Dissertation Improvement Grant from NSF (DEB-1501438). E. Hollenbeck was supported by the NSF Integrative Graduate Education and Research Traineeship program and the NSF Graduate Research Fellowship Program. This study was also funded by Grants from NSF (EAR-141 1942, DEB-1256896, and DEB-1457160) and the Department of Energy Office of Biological and Environmental Research (DE-SC0016410). All fieldwork associated with this study was conducted with a USDA-APHIS PPQ permit (P330-13-00222).

\section{Compliance with ethical standards}

Conflict of interest The authors declare that they have no conflict of interest.

\section{OPEN ACCESS}

This article is distributed under the terms of the Creative Commons Attribution 4.0 International License (http://creativecommons.org/licenses/by/4 $.0 /$ ), which permits unrestricted use, distribution, and reproduction in any medium, provided you give appropriate credit to the original author(s) and the source, provide a link to the Creative Commons license, and indicate if changes were made.

\section{REFERENCES}

Allison SD, Treseder KK. 2008. Warming and drying suppress microbial activity and carbon cycling in boreal forest soils. Glob Change Biol 14:2898-909.
Aubrey DA, Nadkarni NM, Broderick CP. 2013. Patterns of moisture and temperature in canopy and terrestrial soils in a temperate rainforest, Washington. Botany 91:739-44.

Bohlman SA, Matelson TJ, Nadkarni NM. 1995. Moisture and temperature patterns of canopy humus and forest floor soil of a montane cloud forest, Costa Rica. Biotropica 27:13-19.

Caporaso JG, Kuczynski J, Stombaugh J, Bittinger K, Bushman FD, Costello EK, Fierer N, Peña AG, Goodrich JK, Gordon JI and others. 2010. QIIME allows analysis of high-throughput community sequencing data. Nature 7:335-6.

Cardelús CL. 2009. Litter decomposition within the canopy and forest floor of three tree species in a tropical lowland rain forest, Costa Rica. Biotropica 42:300-8.

Cardelús CL, Chazdon RL. 2005. Inner-crown microenvironments of two emergent tree species in a lowland wet forest. Biotropica 37:238-44.

Clark KL, Lawton RO, Butler PR. 2000. The physical environment. In: Nadkarni NM, Wheelwright NT, Eds. Monteverde: ecology and conservation of a tropical montane cloud forest. New York: Oxford University Press. p 15-38.

Coxson DS, Nadkarni NM. 1995. Ecological roles of epiphytes in nutrient cycles of forest ecosystems. In: Lowman M, Nadkarni NM, Eds. Forest canopies. San Diego: Academic Press. p 495543.

Dangerfield CR, Nadkarni NM, Brazelton WJ. 2017. Canopy soil bacterial communities altered by severing host tree limbs. PeerJ 5:e3773.

de Boer W, Folman LB, Summerbell RC, Boddy L. 2005. Living in a fungal world: impact of fungi on soil bacterial niche development. FEMS Microbiol Rev 29:795-811.

Decaëns T. 2010. Macroecological patterns in soil communities. Glob Ecol Biogeogr 19:287-302.

Garnica S, Schön ME, Abarenkov K, Riess K, Liimatainen K, Niskanen $\mathrm{T}$ and others. 2016. Determining threshold values for barcoding fungi: lessons from Cortinarius (Basidiomycota), a highly diverse and widespread ectomycorrhizal genus. FEMS Microbiol Ecol 92:fiw045.

Gentry AH, Dodson C. 1987. Contribution of nontrees to species richness of a tropical rain forest. Biotropica 19:149-56.

German DP, Weintraub MN, Grandy AS, Lauber CL, Rinkes ZL, Allison SD. 2011. Optimization of hydrolytic and oxidative enzyme methods for ecosystem studies. Soil Biol Biogeochem 43:1387-97.

Giauque H, Hawkes CV. 2013. Climate affects symbiotic fungal endophyte diversity and performance. Am J Bot 100:1435-44.

Giauque H, Hawkes CV. 2016. Historical and current climate drive spatial and temporal patterns in fungal endophyte diversity. Fungal Ecol 20:108-14.

Giauque H, Connor EW, Hawkes CV. 2018. Endophyte traits relevant to stress tolerance, resource use and habitat of origin predict effects on host plants. New Phytol 19:432-511.

Goldsmith GR, Matzke NJ, Dawson TE. 2012. The incidence and implications of clouds for cloud forest plant water relations. Ecol Lett 16:307-14.

Gotsch SG, Nadkarni N, Amici A. 2016. The functional roles of epiphytes and arboreal soils in tropical montane cloud forests. J Trop Ecol 32:455-68.

Gotsch SG, Dawson TE, Draguljić D. 2017. Variation in the resilience of cloud forest vascular epiphytes to severe drought. New Phytol 219:900-13. 
Gorbushina AA, Kotlova ER, Sherstneva OA. 2014. Cellular responses of microcolonial rock fungi to long-term desiccation and subsequent rehydration. Stud Mycol 61:91-7.

Hamilton CE, Bauerle TL. 2012. A new currency for mutualism? Fungal endophytes alter antioxidant activity in hosts responding to drought. Fungal Divers 54:39-49.

Hanson CA, Allison SD, Bradford MA, Wallenstein MD, Treseder KK. 2008. Fungal taxa target different carbon sources in forest soil. Ecosystems 11:1157-67.

Häger A, Dohrenbusch A. 2010. Structure and dynamics of tropical montane cloud forests under contrasting biophysical conditions in north-western Costa Rica. In: Bruijnzeel LA, Scatena FN, Hamilton LS, Eds. Tropical montane cloud forests. New York: Cambridge University Press. p 208-16.

Hawkes CV, Kivlin SN, Rocca JD, Huguet V, Thomsen MA, Suttle KB. 2011. Fungal community responses to precipitation. Glob Change Biol 17:1637-45.

Hertel D, Köhler L, Rillig MC. 2011. Mycorrhizal, endophytic and ecomorphological status of tree roots in the canopy of a montane rain forest. Biotropica 43:401-4.

Hietz P, Wanek W, Wania R, Nadkarni NM. 2002. Nitrogen-15 natural abundance in a montane cloud forest canopy as an indicator of nitrogen cycling and epiphyte nutrition. Oecologia 131:350-5.

Inselsbacher E, Cambui CA, Richter A, Stange CF, Mercier $\mathrm{H}$, Wanek W. 2007. Microbial activities and foliar uptake of nitrogen in the epiphytic bromeliad Vriesea gigantea. New Phytol 175:311-20.

Karmalkar AV, Bradley RS, Diaz HF. 2011. Climate change in Central America and Mexico: regional climate model validation and climate change projections. Clim Dyn 37:605-29.

Kivlin SN, Winston GC, Goulden ML, Treseder KK. 2014. Environmental filtering affects soil fungal community composition more than dispersal limitation at regional scales. Fungal Ecol 12:14-25.

Lawton RO, Nair US, Pielke RA Sr, Welch RM. 2001. Climatic impact of tropical lowland deforestation on nearby montane cloud forests. Science 294:584-7.

Looby CI, Maltz MR, Treseder KK. 2016. Belowground responses to elevation in a changing cloud forest. Ecol Evol 6:19962009

Malhi Y, Silman M, Salinas N, Bush M, Meir P, Saatchi S. 2010. Elevation gradients in the tropics: laboratories for ecosystem ecology and global change research. Science 16:3171-5.

Maffia B, Nadkarni NM, Jones DP. 1993. Vesicular-arbuscular mycorrhizae of epiphytic and terrestrial Piperaceae under field and greenhouse conditions. Mycorrhiza 4:5-9.

McGuire KL, Bent E, Borneman J, Majumder A, Allison SD, Treseder KK. 2010. Functional diversity in resource use by fungi. Ecology 91:2324-32.

McGuire KL, Fierer N, Bateman C, Treseder KK, Turner BL. 2011. Fungal community composition in neotropical rain forests: the influence of tree diversity and precipitation. Microb Ecol 63:804-12.

Nadkarni NM. 1984. Epiphyte biomass and nutrient capital of a neotropical elfin forest. Biotropica 16:249-56.

Nadkarni NM, Schaefer D, Matelson TJ, Solano R. 2002. Comparison of arboreal and terrestrial soil characteristics in a lower montane forest, Monteverde, Costa Rica. Pedobiologia 46:2433.

Nadkarni NM, Schaefer D, Matelson TJ. 2004. Biomass and nutrient pools of canopy and terrestrial components in a pri- mary and a secondary montane cloud forest, Costa Rica. For Ecol Manag 198:223-36.

Nadkarni NM. 2010. Potential effects of global climate change on epiphytes in a tropical montane cloud forest: an experimental study from Monteverde, Costa Rica. In: Bruijnzeel LA, Scatena FN, Hamilton LS, Eds. Tropical montane cloud forests. New York: Cambridge University Press. p 557-65.

Nair US, Lawton RO, Welch RM. 2003. Impact of land use on Costa Rican tropical montane cloud forests: sensitivity of cumulus cloud field characteristics to lowland deforestation. J Geophys Res 108(D7):4206.

Nguyen NH, Song Z, Bates ST, Branco S, Tedersoo L, Menke J, Schilling JS, Kennedy PG. 2016. FUNGuild: an open annotation tool for parsing fungal community datasets by ecological guild. Fungal Ecol 20:241-8.

Oksanen J and others. 2017. Vegan: community ecology package. $\mathrm{R}$ package version 2.4-2.

Orlovich DA, Draffin SJ, Daly RA, Stephenson SL. 2013. Piracy in the high trees: ectomycorrhizal fungi from an aerial "canopy soil" microhabitat. Mycologia 105:52-60.

Pinheiro J, Bates D, DebRoy S, Sarkar D. 2016. Nlme: linear and nonlinear mixed effects models. R package version 3.1-128.

Pittl E, Innerebner G, Wanek W, Insam H. 2010. Microbial communities of arboreal and ground soils in the Esquinas rainforest, Costa Rica. Plant Soil 329:65-74.

Pounds JA, Bustamante MR, Coloma LA, Consuegra JA, Fogden MPL, Foster PN, La Marca E, Masters KL, Merino-Viteri A, Puschendorf $\mathrm{R}$ and others. 2006. Widespread amphibian extinctions from epidemic disease driven by global warming. Nature 439:161-7.

Pounds JA, Fogden M, Campbell JH. 1999. Biological response to climate change on a tropical mountain. Nature 398:611-15.

Rains KC, Nadkarni NM, Bledsoe CS. 2003. Epiphytic and terrestrial mycorrhizas in a lower montane Costa Rican cloud forest. Mycorrhiza 13:257-64.

Rodriguez RJ, Henson J, Van Volkenburgh E, Hoy M, Wright L, Beckwith F, Kim Y-O, Redman RS. 2008. Stress tolerance in plants via habitat-adapted symbiosis. ISME J 2:404-16.

Rousk J, Nadkarni NM. 2009. Growth measurements of saprotrophic fungi and bacteria reveal differences between canopy and forest floor soils. Soil Biol Biochem 41:862-5.

Schneider T, Keiblinger KM, Schmid E, Sterflinger-Gleixner K, Ellersdorfer G, Roschitzki B, Richter A, Eberl L, ZechmeisterBoltenstern S, Riedel K. 2012. Who is who in litter decomposition? Metaproteomics reveals major microbial players and their biogeochemical functions. ISME J 6:1749-62.

Setälä H, McLean MA. 2004. Decomposition rate of organic substrates in relation to the species diversity of soil saprophytic fungi. Oecologia 139:98-107.

Sinsabaugh RL, Lauber CL, Weintraub MN, Ahmed B, Allison SD, Crenshaw C, Contosta AR, Cusack D, Frey S, Gallo ME and others. 2008. Stoichiometry of soil enzyme activity at global scale. Ecol Lett 11:1252-64.

Still CJ, Foster PN, Schneider SH. 1999. Simulating the effects of climate change on tropical montane cloud forests. Nature 398:608-10.

Sundqvist MK, Sanders NJ, Wardle DA. 2013. Community and ecosystem responses to elevational gradients: processes, mechanisms, and insights for global change. Ann Rev Ecol Evol Syst 44:261-80. 
Townsend AR, Cleveland CC, Houlton BZ, Alden CB, White JW. 2011. Multi-element regulation of the tropical forest carbon cycle. Front Ecol Environ 9:9-17.

Treseder KK, Lennon JT. 2015. Fungal traits that drive ecosystem dynamics on land. Microbiol Mol Biol Rev 79:243-62.

Vance ED, Nadkarni NM. 1990. Microbial biomass and activity in canopy organic matter and the forest floor of a tropical cloud forest. Soil Biol Biochem 22:677-84.
Woods CL, Cardelús CL, DeWalt SJ. 2015. Microhabitat associations of vascular epiphytes in a wet tropical forest canopy. $\mathrm{J}$ Ecol 103:421-30.

Yancey PH. 2005. Organic osmolytes as compatible, metabolic and counteracting cytoprotectants in high osmolarity and other stresses. J Exp Biol 208:2819-30.

Zimmerman NB, Vitousek PM. 2012. Fungal endophyte communities reflect environmental structuring across a Hawaiian landscape. PNAS 109:13022-7. 